\title{
COMPARISON OF LONG-TERM PROGESTERONE-BASED PROTOCOL ON REPRODUCTIVE PERFORMANCE OF PREPUBERTAL AND PUBERTAL BEEF HEIFERS
}

\author{
Emanoel Faleiros Silveira ${ }^{1}$, Luiz Ernandes Kozicki' ${ }^{1}$, Marcio Saporski Segui', \\ Romildo Romualdo Weiss², Ivo Walter Santos' ${ }^{2}$, Melina Andrea Formighieri Bertol ${ }^{2}$ \\ 1 PUCPR \\ 2 UFPR \\ Correspondência: Luiz Ernandes Kozicki: kozicki.I@pucpr.br
}

\begin{abstract}
The aim of this study was to investigate estrus synchronization in prepubertal and pubertal heifers (crossbred $1 / 2$ Nelore $x$ Red Angus - commercial herd) submitted to a long-term progesterone-based protocol for timed artificial insemination (TAI), as well as overall pregnancy rates. Four hundred forty-seven heifers underwent ultrasound examination of the ovaries and were assigned to one of 3 groups: (1) prepubertal heifers (PPNS; $n=114$ ) with ovarian follicles $<8 \mathrm{~mm}$ in diameter and no corpus luteum (CL) that were submitted to natural service (NS) by bulls for 10 days; (2) prepubertal heifers (PPTAl; $\mathrm{n}=124$ ) with follicles $<8 \mathrm{~mm}$ in diameter and no $\mathrm{CL}$ that underwent estrus synchronization with injection of $4.0 \mathrm{mg}$ estradiol benzoate (EB) and insertion of a controlledrelease intravaginal progesterone (P4) device containing $0.558 \mathrm{~g} \mathrm{P} 4$ on d 0, followed by P4 device removal and injection of $150 \mathrm{mg}$ prostaglandin $\mathrm{F} 2 \alpha$ and $0.6 \mathrm{mg}$ estradiol cypionate (ECP) on $\mathrm{d} 8$, and TAI on d 10; and (3) pubertal heifers (PTAl; $n=209$ ) with follicles $>8 \mathrm{~mm}$ in diameter and/or a CL that underwent the same protocol as PPTAI heifers. Overall pregnancy rate was determined by transrectal ultrasonography on d 45 after NS or TAI. Data were analyzed using the FREQ procedure of SAS (SAS Inst. Inc., Cary, NC). Pregnancy rates were as follows: $20.1 \%$ in PPNS, $37.0 \%$ in PPTAI, and $48.5 \%$ in PTAI $(P<0.05)$. In conclusion, TAl after estrus synchronization with a hormonal protocol using EB and ECP in prepubertal and pubertal heifers resulted in higher pregnancy rates than prepubertal heifers exposed to natural service, and exposure of prepubertal heifers to a long-term progesterone-based protocol effectively synchronized estrus.
\end{abstract}

Key Words: pre pubertal; pubertal heifers; progesterone; TAI

\section{COMPARAÇÃO DE UM PROTOCOLO BASEADO EM PROGESTERONA SOBRE A PERFORMANCE REPRODUTIVA DE NOVILHAS PRÉ-PUBERES E PUBERES DE CORTE}

RESUMO: O objetivo do estudo foi verificar a sincronização do estro e a taxa geral de prenhez em novilhas cruzadas (1/2 Nelore $x$ Red Angus) pré-púberes e púberes (rebanho comercial), submetidas a protocolo com progesterona visando a inseminação artificial em tempo fixo (IATF). Quatrocentas e quarenta e sete novilhas foram submetidas a exame ultrassonográfico dos ovários e distribuídas em grupos: 1 . novilhas pré-púberes (PPNS; $n=114$ ) com folículos ovárianos $<8 \mathrm{~mm}$ de diâmetro e sem corpo lúteo $(\mathrm{CL})$, submetidas à cobertura natural (NS) por 10 dias; 2. Novilhas pré-púberes (PPTAl; $\mathrm{n}=124$ ) com folículos ovarianos $<8 \mathrm{~mm}$ de diâmetro e sem $\mathrm{CL}$, submetidas à sincronização do estro mediante injeção de $4.0 \mathrm{mg}$ de benzoato de estradiol (EB) e inserção de dispositivo intravaginal com progesterona (P4) contendo $0,558 \mathrm{~g}$ de $\mathrm{P} 4$ no dia 0 (d 0), seguido de remoção do dispositivo de P4 e injeção de $150 \mathrm{mg}$ de prostaglandina F2 alfa e $0,6 \mathrm{mg}$ de cipionato de estradiol (ECP) no d 8, e IATF no d 10; e 3. Novilhas púberes (PTAl; $n=209$ ) com foliculos $>8 \mathrm{~mm}$ de diâmetro e ou com $\mathrm{CL}$, submetidas ao mesmo protocolo das novilhas PPTAI. O diagnostico de prenhez foi determinado por ultrassonografia transretal no $45^{\circ}$ dia após o NS ou a IATF. Os dados foram analisados utilizando o soft SAS (SAS - Inst.Inc., Cary,NC). taxa de prenhez: $20,1 \%$ no PPNS, $37.0 \%$ no PPTAI e $48,5 \%$ no PTAI $(P<0,05)$. Concluiu-se que a IATF após a sincronização do estro com protocolo hormonal utilizando EB e ECP em novilhas pré-púberes e púberes, resultou em mais elevada taxa de prenhez do que em novilhas pré-púberes expostas aos touros, e que a exposição das novilhas pré-púberes a protocolo com progesterona efetivamente sincronizou o estro.

Palavras-chave: novilhas pré- púberes; púberes; progesterona; IATF 


\section{INTRODUCTION}

Brazil has the largest commercial herd in the world-approximately 200 million animals (IBGE, 2004). Farms need to achieve good zootechnical performance and positive financial results to become profitable as quickly as possible. Low reproductive efficiency in herdsis the main cause of persistently low production rates. Therefore, animal factors, such as age, category, body condition score, reproductive health (ovaries and uterus), and calving season (Cunha, 2011), need to be taken into account when planning the reproductive strategy for each farm.

According to Soares and Araldi (2011), a critical factor in the beef industry remains low fertility of the cows in breeding herds and consequent low calving rates. Taira et al. (2010) concluded that efficiency in the calving period is a determining factor in the economic viability of production systems. In addition, the Brazilian beef cattle industry is still conducted as an extractive activity, with minimal use of inputs and biotechnology (Santos et al., 2011), which further limits economic viability.

The use of timed artificial insemination (TAI) for increasing the productivity of breeding herds is recommended by Viana et al. (2008) and Taira et al. (2010). This biotechnology has advantages over natural breeding and minimizes the variables that contribute negatively in traditional artificial insemination (Al), such as failures in the detection of estrus.

Baruselli et al. (2007) report that the difficulties of estrus detection are more pronounced in Bos indicus cows, which show physiological estrus for a short period and at night. According to Moraes and Souza (2008), TAI programs substantially reduce this problem, because estrus observation is unnecessary, and TAl allows shortening of the postpartum period.

Synchronization of estrus is less successful in heifers than pluriparous cows. Physiological factors in heifers may hinder synchronization of ovulation because of individual or breed variation in blood levels of progesterone (P4) at the time of intravaginal device removal. Synchronization of estrus in heifers may also result in lower pregnancy results because of age and/or low level of body development in the first breeding season. According to Sá Filho et al. (2008), puberty is delayed in Bos indicus heifers because of seasonality of forage production, poor management of pasture, and low food supplementation during the growth phase. A significant number of prepubertal animals (Nelore bred) are older than 2 years of age because of low body weight, low fat reserves, and low genetic selection.

Hormonal protocols for TAI in lactating beef cows show decreased effectiveness when used in heifers (Sá Filho et al., 2008). Differences in reproductive physiology between Bos taurus and Bos indicus cattle may also affect responses to synchronization protocols. P4 levels during the estrous cycle are an important influencing factor.

Carvalho (2004) showed that an intravaginal P4 device combined with estradiol benzoate (EB) or estradiol cypionate (ECP) (Wheaton and Lahm, 2007) caused dominant follicle atresia at the start of the treatment and synchronized the emergence of a new follicular wave in Bos indicus, Bos taurus $x$ Bos indicus, and Bos taurus cows; further, Bos indicus heifers displayed significantly lower growth rate, lower diameter of the dominant follicle, and lower rate of ovulation than Bos taurus.

The present study investigated synchronization of estrus in prepubertal and pubertal heifers submitted to a longterm progesterone-based protocol for TAl. 


\section{MATERIAL AND METHODS}

This study included 447 crossbred heifers ( $1 / 2$ Nelore $x$ Red Angus) from a commercial herd, aged 24-28 months, with average body condition score of 6.50 (scale of $1=$ thin to $9=$ obese) and weight of $325 \mathrm{~kg}$. The heifers were maintained on Brachiaria brizantha, with mineral salt and water ad libitum. Before the study began, the ovaries were assessed by ultrasound examination (Tringa model, $5-\mathrm{MHz}$ transducer; Pie Medical), to check for the presence of follicles greater than or less than $8 \mathrm{~mm}$ in diameter and corpora lutea. Three groups were assigned: (1) prepubertal (PPNS; $\mathrm{n}=114$ ) with follicles $<8 \mathrm{~mm}$ in diameter and no corpus luteum (CL) served by bulls in a natural service (NS) for 10 days; (2) prepubertal (PPTAI; $\mathrm{n}=$ 124) with follicles $<8 \mathrm{~mm}$ in diameter and no $C L$ that underwent estrus synchronization with injection of $4.0 \mathrm{mg}$ estradiol benzoate $\left(\mathrm{EB}\right.$; Cronibest $^{\circledR}, \mathrm{BE}$, Biogenesis-Bagó Animal Health Ltd) and insertion of a controlled-release intravaginal progesterone (P4) device (Cronipres $^{\circledR}, 0.558$ g P4; BiogenesisBagó Animal Health Ltd) on d 0, followed by $\mathrm{P} 4$ device removal and injection of $150 \mathrm{mg}$ prostaglandin $\mathrm{F}_{2 \alpha}\left(\right.$ Croniben $^{\circledR}$, Dcloprostenol; Biogenesis-Bagó Animal Health Ltd) and $0.6 \mathrm{mg}$ estradiol cypionate $\left(E C P^{\circledR}\right.$ estradiol cypionate; Pfizer Animal Health Laboratory) on d 8, and TAI on d 10; and (3) pubertal heifers (PTAl; $\mathrm{n}=209$ ) with follicles $>8 \mathrm{~mm}$ in diameter and/or a $C L$ that underwent the same protocol as PPTAI heifers. Overall pregnancy rate was determined by transrectal ultrasonography on d 45 after NS or TAl. All the TAl heifers were inseminated with frozen-thawed semen.

Protocols to the PPTAI and PTAI groups.

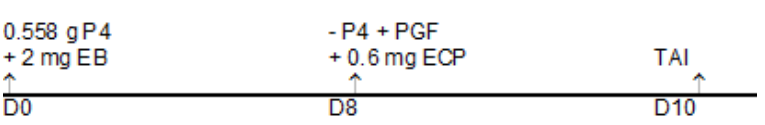

Statistical analysis

Data of pregnancy rates in the groups of heifers were analyzed using Fisher's exact test and the FREQ procedure of SAS (SAS Inst. Inc., Cary, NC) at a significance level of $95 \%$ probability.

\section{RESULTS AND DISCUSSION}

The results are presented in table 1.

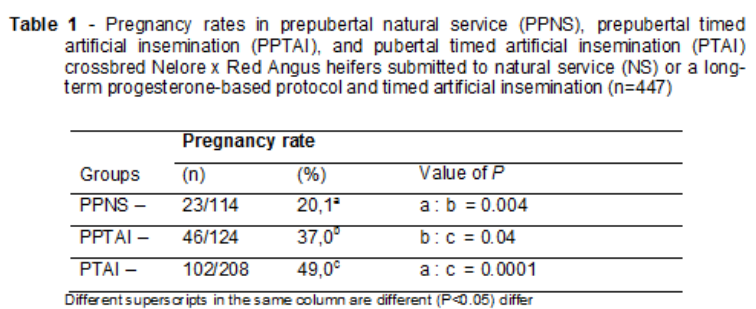

Pregnancy rates in beef heifers with TAI have yielded conflicting results. TAI is influenced by several factors, such as stage of the estrous cycle at the beginning of the protocol, animal category (heifers, primiparous, pluriparous), breed, body condition score, and semen quality (Gofert, 2008; Marques et al., 2008; Sá Filho et al., 2010; Soares and Araldi, 2011).

In this study, pregnancy rate (Table 1) differed significantly among groups. The animals submitted to the long-term progesterone-based protocol had significantly better pregnancy rates, $49.0 \%$ in PTAl and $37.0 \%$ in PPTAI, than the animals submitted to natural service (PPNS). The data suggest the favorable influence of the intravaginal progesterone protocol. There were also significant differences between PPTAI and PTAl heifers $(P<0.05)$, which emphasizes the significant performance of the protocol in animals that are already cycling. Pfeifer et al.(2008) and Sá Filho et al. (2010), in TAl programs in beef heifers in Brazil, have reported higher pregnancy rates in pubertal than prepubertal heifers, corroborating data of the present study.

Comparison between PPNS and PPTAl heifers suggested a marked 

prepubertal and pubertal beef heifers

advantage of the long-term progesterone-based protocol $(P<0.01)$ The pregnancy rate in PPTAl heifers $(37.0 \%)$ confirmed that cyclicity of the ovaries can be induced in animals exposed to P4, even females in anestrus (Azeredo et al., 2007; Leitmann et al., 2009; Pereira, 2010). The PTAI heifers showed the best response to the study protocol $(P<0.04)$, corroborating reports of Sá Filho et al. (2010) stating that the P4 protocol performs best in cycling animals. Sá Filho et al. (2010) reported that the P4-based protocol induced greater cyclical ovarian activity, and even increased uterine diameter, in prepubertal crossbred (Bos taurus x Bos indicus) heifers. Using a similar protocol to that of the present study (ECP use at P4 removal), Sá Filho et al. (2010) obtained a pregnancy rate of $48.0 \%$ in treated prepubertal heifers versus $18.7 \%$ in untreated heifers-higher performance than that in the PPTAI heifers in the present study $(37.0 \%)$ and close to that in the PPNS heifers (20.1\%).

Claro Junior et al. (2010) evaluated the effects of P4 on reproductive performance in prepubertal heifers. They yielded the following results in 3 groups: $27.3 \%$ pregnancy rate in untreated animals, $33.7 \%$ in animals treated with an intravaginal device at the first use (more P4), and $46.8 \%$ in animals with an intravaginal device at the 4th use (less P4). These results are also discrepant but closer to those of the present study (37.0\%). Our results are similar to those of Pfeifer et al. (2008) regarding $35 \%$ pregnancy rate in prepubertal inseminated heifers, but less in relation to pubertal heifers $(60.3 \%$ versus our result of $49.0 \%$ ).

Previous studies show conflicting TAI results (pregnancy rate in prepubertal or even pubertal animals). Further study is warranted focusing on hormonal protocol (e.g., use of an inductor of ovulation), timing of TAI application (with regards to synchronization of estrus or ovulation), and quantity of available P4 in heifers. Heifers treated with lower levels of P4 in the vaginal pessary produced higher pregnancy rate (Claro et al., 2010) and increased diameter of the dominant follicle after device removal (Pegorer, 2009). In addition, Rocha et al. (2007) stated that P4 treatment is essential for $\mathrm{TAl}$, but questioned the advantage and viability of successive reuse of $P 4$ pessaries. Pegorer (2009) used eCG at the time of $\mathrm{P} 4$ removal in heifers and observed no differences (size of the dominant follicle, ovulation rate, and pregnancy rate) between groups. The same study evaluated the use of different P4 pessaries, noting that heifers with a smaller amount of P4 showed increased size of the dominant follicle at the time of device removal (Day 9), results also obtained by Santos et al. (2011).

Azevedo et al. (2007) stated that synchronization of estrus using long-term progesterone for TAI in heifers resulted in beneficial effects on the timing of calving and on repeat conception in the next breeding season. Calving rate was significantly different between primiparous animals that received treatment in the first breeding season and those that received no treatment in the first breeding season. Application of a TAl protocol in heifers in the first breeding season resulted in higher pregnancy rate in the next breeding season.

\section{CONCLUSION}

In conclusion, hormonal protocols using EB and ECP for PPTAI and PTAI resulted in better pregnancy rates than that in PPNS heifers, and exposure of prepubertal heifers to a long-term progesterone-based protocol was effective in estrus synchronization. 


\section{REFERENCES}

AZEREDO, D.M.; ROCHA, D.M.; JOBIM, M.I.M. et al. Estrous induction and synchronization in beef heifers and their effects on the pregnancy rate and at their performance on the second reproductive season. Ciencia Rural, v.37, n.1, p.201-205, 2007.

BARUSELLI, P.S.; GIMENEZ, L.U.; SOUZA SALES, J.N. Reproductive phisiology in Bos taurus and Bos indicus cows. Revista Brasileira de Reprodução Animal, v.31, n.2, p.205$211,2007$.

CARVALHO, J.B.P. Synchronization of ovulation with intravaginal progesterone device(CIDR $\AA$ ) in Bos indicus, Bo staurus and Bos indicus $x$ Bos taurus. São Paulo, 2004. 124p. Thesis, Veterinary Medicine and Animal Science Faculty, University of São Paulo.

CLARO JÚNIOR, I.; SÁ FILHO, O.G.; PERES, R.F.G. et al. Reproductive performance of prepubertal Bos indicus heifers after progesterone-based treatments.

Theriogenology, v.74, n.6, p.903-911, 2010.

CUNHA, R.R. Fixed-time artificial insemination inprimiparous cyclingNelore. Alfenas, 2011. 45p. Dissertation (Master of Science Degree in Animal Reproduction). University José do Rosário Vellano.

GOFERT, L.F. Fixed time artificial insemination(TAI) programs. Technical and economic aspects. In: Symposium on reproduction in cattle,I.2008Pelotas, Proceedings ...Pelotas: EMBRAPA Clima Temperado. 2008, p.41-47.

IBGE (Brazilian Institute of Geography and Statistics) Sense,2004.

LEITMAN, N.R.; BUSCH, D.C.; MALLORY, D.A. et al. Comparison of long-term CIDR-based protocols to synchronize estrus in beef heifers. Animal Reproduction Science,v.114, p.345355, 2009.

MARQUES, M.O.; BARREIROS, T.R.R.; MAX, M.C. et al. TAl: Challenges and solutions to maximize the technique efficiency. Acta

Scientiae Veterinariae, v.36, p.155-160, 2008.

MORAES, J.C.F.; SOUZA, C.J.H. Assessment of body condition and fertility in beef cattle. In:

Symposium of bovine reproduction, I.2008Pelotas, Proceedings..., Pelotas, EMBRAPA Clima Temperado, 2008, p.31-40.
PEGORER, M.F. Ovulation and pregnancy rates in cycling Nelore heifers after use of protocols for fixed-time artificial insemination(TAI), under different concentrations of progesterone, associated or not to eCG. Botucatu, 2009. 89p. Thesis, Veterinary Medicine and Animal Science Faculty, State University of São Paulo.

PEREIRA, C.H. Early luteolysis under progesterone fixed time artificial insemination protocol in goats along postpartum. Porto Alegre, 2010. 39p. Dissertation, Veterinary Faculty , Federal University of Rio Grande do Sul.

PFEIFER, L.F.M.; SCHNEIDER, A.; SILVA NETO, J.W. et al. Biological and economic evaluation flunixinmeglumine in cows and heifers beef inseminated at fixed time. Revista Brasileira de Zootecnia, v.37, n.8, p.1392-1397, 2008.

ROCHA, J.M.; RABELO, M.C.; SANTOS, M.H.B. et al. TAl in Nellore cows: Evaluation of two doses of eCG and reuse of intravaginal progesterone implants. Medicina Veterinaria, v.1, n.1, p.40-47, 2007.

SÁ FILHO, M.F.; GIMENES, L.U.; SALES, J.N.S. et al. TA linheifers. In:International Symposium on Applied Animal Reproduction, III. 2008, Londrina, Proceedings... Londrina: 2008, p. 5467,2008

SÁ FILHO, M.F.; AYRES, H.; FERREIRA, R.M. et al. Equine chorionic gonadotropin and gonadotropin-releasing hormone enhance fertility in a norgestomet-based, timed artificial insemination protocol in suckled Nelore (Bos indicus) cows. Theriogenology, v.73, n.5, p.651-658, 2010.

SANTOS, K.J.G.; SANTOS, C. P.; VIEIRA, J.A. et al. Comparison of estrusand conception rate in Nelore cows submitted to techniques of reproductive stimulus. Revista Faculdade de Montes Belos, v.4, n.2, p.49-55, 2011.

SOARES, J.F.B.; ARALDI, D.F. Main limitations in reproductive postpartum period in beef cows. In: Inter institutional Seminar to Teaching, Research and Extension, XVI. 2011, Cruz Alta, Proceedings... Cruz Alta: Veterinary Medicine Faculty of the UNICRUZ, 2011, p. 34-38, 2011.

TAIRA, E.M.; PINTO, F.L.; RAMO, L.D. et al. Use of $\mathrm{LH}$ to induction of ovulation in TAI protocol for heifers. Colloquium Agraria,v.6, p.43-49, 2010. 
VIANNA, G.N.O.; KOZICKI, L.E.; WEISS, R.R.

et al. Comparison of different protocols for estrus synchronization and fixed-time artificial

insemination in Nelore cows under postpartum

anestrus. Archives of Veterinary

Science,v.13, n.4, p.247-254, 2008.

WHEATON,J.E.; LAMB, G.C. Induction of

cyclicity in postpartum anestrous beef cows using

progesterone, $\mathrm{GnRH}$ and estradiol cypionate.

(ECP). Animal Reproduction Science,v.102,

p.208-216, 2007. 